\title{
Paramolgus orientalis n. sp. (Copepoda: Cyclopoida: Rhynchomolgidae) Associated with an Antipatharian Coral from Korea
}

\author{
Mi-Kyung Choe ${ }^{1}$ and Il-Hoi Kim²,* \\ ${ }^{1}$ Jeju Fisheries Research Institute, National Fisheries Research \& Development Institute, \\ Jeju 690-192, Korea \\ ${ }^{2}$ Department of Biology, Kangnung National University, Gangneung 210-702, Korea
}

\begin{abstract}
Paramolgus orientalis n. sp. is described as an associate of the antipatharian coral Antipathes japonicus from Jeju Island, Korea. The new species is distinguished from its three relatives $P$. constrictus, $P$. delicatulus, and $P$. insectus, all known from antipatharians in tropical waters, by its long caudal ramus which is more than four times as long as wide, by the possession of 4 setae on maxillule, and by other morphological differences in the antenna and maxilla.
\end{abstract}

Keywords: Paramolgus orientalis n. sp., copepoda, association, Antipatharia, Korea

\section{INTRODUCTION}

Antipatharian corals are utilized as hosts by many symbiotic invertebrates such as copepods, brittle stars, and decapods, and many of these symbiotic organisms are species-specific (Opresco and Sanchez, 2005). The copepods symbiotic on the antipatharians include the genera such as Calonastes (1 species), Paramolgus (3 spp.), Camotesia (1 sp.), Thamnomolgus (2 spp.), Vahinius (2 spp.) and Visayasia (2 spp.) in the order Cyclopoida and Asteropontius (3 spp.) and Orecturus (1 sp.) in the order Siphonostomatoida.

In Korea only two species of copepods have been found on the antipatharian coral. They are Thamnomolgus robustus Humes, 1969 and Asteropontius bifurcatus Kim and Je, 2000 from Antipathes japonicus Brook (Kim, 1998; Kim and Je, 2000). In the present paper a new species of Paramolgus will be described as an associate of Antipathes japonicus from Jeju Island, Korea.

The genus Paramolgus is a large genus in the family Rhynchomolgidae. Species of this genus are associated with various cnidarians and currently contains 33 species (Kim, 2006). Of these, three species are known as associates of antipatharian corals: $P$. constrictus Humes, 1969 from Madagascar (Humes, 1969) and P. insectus Humes, 1969 from the Madagascar, the Moluccas, and the Philippines (Humes, 1969,

\footnotetext{
*To whom correspondence should be addressed

Tel: 82-33-640-2312, Fax: 82-33-642-6124

E-mail: ihkim@kangnung.ac.kr
}

1979, 1992), and P. delicatulus Humes, 1992 from the Philippines (Humes, 1992).

\section{SYSTEMATIC ACCOUNTS}

Family Rhynchomolgidae Humes and Stock, 1972

1*Genus Paramolgus Humes and Stock, 1972

$2 *$ Paramolgus orientalis n. sp. (Figs. 1-3)

Material examined. 2 우 우 $4 \sigma^{7} \sigma^{7}$ from washings of the antipatharian Antipathes japonicus Brook, off Sagye-ri (approximately $33^{\circ} 12^{\prime} 27^{\prime \prime} \mathrm{N}, 126^{\circ} 59^{\prime} 01^{\prime \prime} \mathrm{E}$ ), south of Jeju Island, 22 September 2009, collected by M.-K. Choe. Holotype (우), allotype ( $\sigma^{\Im}$ ) and paratypes ( $2 \sigma^{\nearrow}$ ) will be deposited in the National Institute of Biological Resources, Incheon, Korea.

Female. Body (Fig. 1A) moderately narrow. Body length of dissected paratype $1.64 \mathrm{~mm}$. Maximum width $600 \mu \mathrm{m}$. Prosome $951 \mu \mathrm{m}$ long. Cephalothorax $610 \times 600 \mu \mathrm{m}$, divided by dorsal suture line into cephalosome and first pedigerous somite. Second pedigerous somite posterolaterally produced. Urosome 5-segmented. Fifth pedigerous somite $183 \mu \mathrm{m}$ wide. Genital double-somite $225 \times 197 \mu \mathrm{m}$, divided by distinct lateral incision into roundly expanded anterior $2 / 3$ and narrower posterior 1/3 (Fig. 1B); narrower posterior part 128 $\mu \mathrm{m}$ wide; genital areas located dorsally in midway of anterior part. Three free abdominal somites $70 \times 100,52 \times 84$, and $85 \times 110 \mu \mathrm{m}$, respectively; second abdominal somite nar-

\footnotetext{
1 *산호더부살이속 (신칭), ${ }^{2 *}$ 해송더부살이 (신칭),
} 


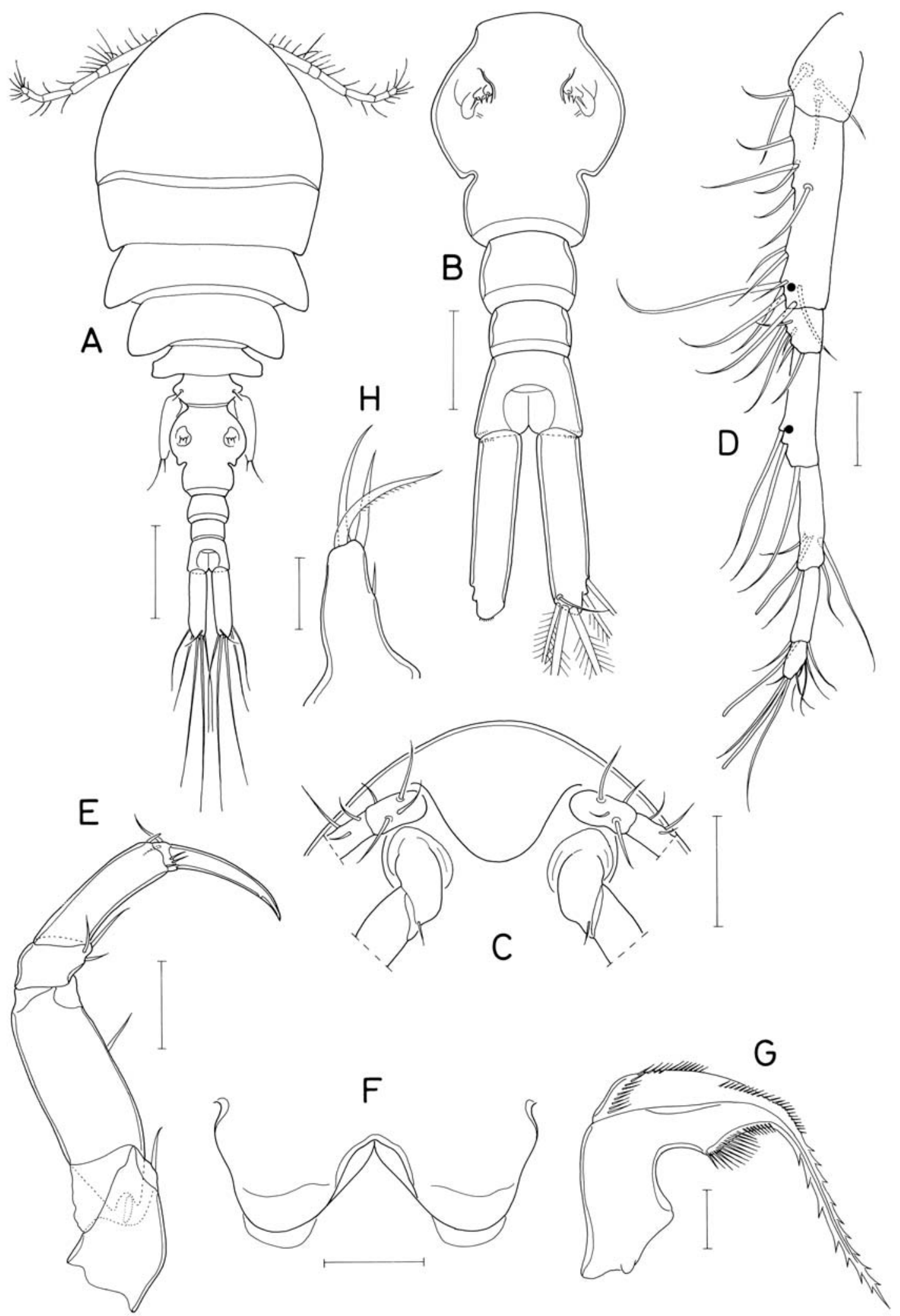

Fig. 1. Paramolgus orientalis n. sp., female. A, habitus, dorsal; $B$, genital double-somite and abdomen, dorsal; $C$, rostral area, ventral; $D$, antennule; $E$, antenna; $F$, labrum; $G$, mandible; $H$, maxillule. Scales: $A=0.2 \mathrm{~mm}$; $B, C=0.1 \mathrm{~mm} ; \mathrm{D}-\mathrm{F}=0.05 \mathrm{~mm}$; $\mathrm{G}, \mathrm{H}=$ $0.02 \mathrm{~mm}$. 

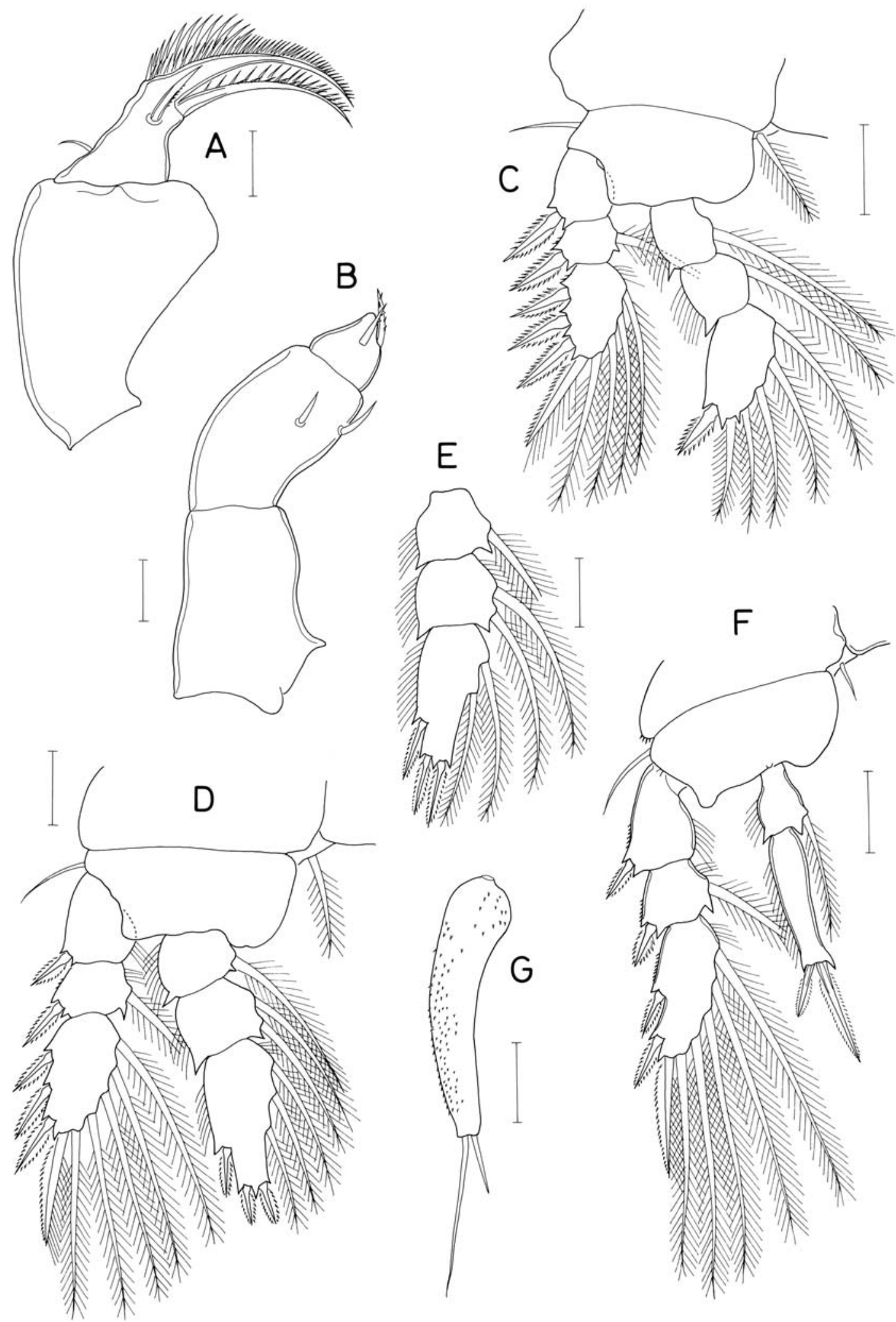

Fig. 2. Paramolgus orientalis n. sp., female. A, maxilla; $B$, maxilliped; $C$, leg 1 ; $D$, leg 2; $E$, leg 3 endopod; F, leg 4; G, free segment of leg 5. Scales: $A, B=0.2 \mathrm{~mm} ; C-G=0.05 \mathrm{~mm}$. 


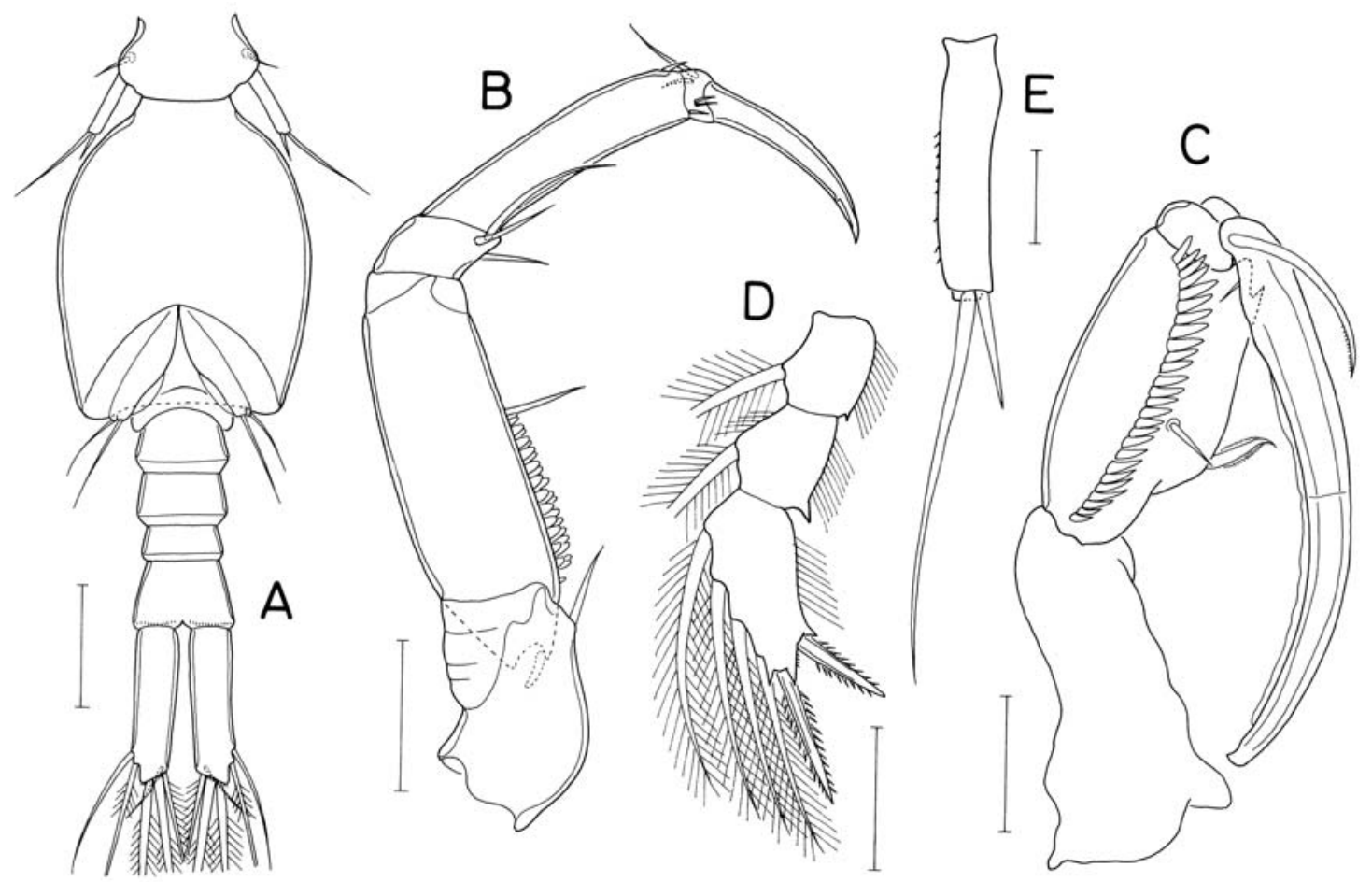

Fig. 3. Paramolgus orientalis n. sp., male. A, urosome, ventral; B, antenna; C, maxilliped; D, leg 1 endopod; E, free segment of leg 5. Sclaes: $A=0.1 \mathrm{~mm} ; B-D=0.05 \mathrm{~mm} ; E=0.02 \mathrm{~mm}$.

rower than preceding and following somites. Anal somite trapezoid, with fine spinules on posterolateral border both dorsally and ventrally. Caudal rami well isolated from each other; each ramus $190 \times 45 \mu \mathrm{m}, 4.22$ times as long as wide, with 6 setae; outer lateral seta located subdistally.

Rostrum large and hemicircular (Fig. 1C). Antennule (Fig. 1D) 7-segmented; numbers of setae 4, 13, 6, 3, 4, 2, and 7 on first to last segment; distal 3 segments each with 1 aesthetasc, in addition to setae; all setae smooth. Antenna (Fig. 1E) 4-segmented, with 1 terminal claw; first and second segments each armed with 1 inner seta; short third segment with 3 inner setae; fourth segment $83 \times 25 \mu \mathrm{m}, 3.32$ times as long as wide, distally with 6 small setae; terminal claw $75 \mu \mathrm{m}$ long, slightly curved.

Labrum (Fig. 1F) with broad posterior incision; both lobes fringed with broad membrane on posterior margin. Mandible (Fig. 1G) with broad proximal notch; inner margin with setules proximally and spinules distally; convex margin with row of spinules; distal lash elongate with serrate margins. Maxillule (Fig. 1H) with 1 small lateral seta and 3 larger distal setae. Maxilla (Fig. 2A) 2-segmented; proximal segment unarmed; distal segment with small proximal seta; spiniform anterior seta, and large inner seta bearing 3 rows of spinules on distal margin; distal lash as long as inner seta, with 1 row of spinules and additional row of larger spinules on proximal half of distal margin. Maxilliped (Fig. 2B) 3-segmented; first segment unarmed; second segment nearly as long as first; with 2 smooth similar setae; terminal segment terminated by nipple shaped process and armed with 2 setae subdistally, one of them spinule-bearing and spiniform.

Legs 1-3 with 3-segmented rami. Leg 4 with 3-segmented exopod and 2-segmented endopod. Legs 1-4 with smooth outer seta on basis (Fig. 2C, D, F). Leg 4 (Fig. 2F) with second endopodal segment of $83 \times 23 \mu \mathrm{m}$; its 2 distal spines 32 (outer) and $65 \mu \mathrm{m}$ long. Armature formula of legs $1-4$ as follows:

Leg 1: coxa 0-1; basis 1-0; exp. I-0; I-1; III,I,4; enp. $0-1 ; 0-1 ; \mathrm{I}, 1,4$

Leg 2: coxa 0-1; basis 1-0; exp. I-0; I-1; III,I,5; enp. $0-1 ; 0-2 ; \mathrm{I}, \mathrm{II}, 3$

Leg 3: coxa 0-1; basis 1-0; exp. I-0; I-1; III,I,5; enp. $0-1 ; 0-2 ; \mathrm{I}, \mathrm{II}, 2$

Leg 4: coxa 0-1; basis 1-0; exp. I-0; I-1; II,I,5; enp. $0-1$; II

Leg 5 consisting of small dorsolateral seta on fifth pedigerous somite and free segment; free segment (Fig. 2G) slightly expanded proximally and gradually narrowed distally, with many scattered minute spinules (or scales) and 2 terminal setae of 100 (outer) and $40 \mu \mathrm{m}$ (inner). Leg 6 represented by 2 small setae in genital area (Fig. 1B). 
Male. Body narrower than that of female. Body length of dissected specimen $1.38 \mu \mathrm{m}$. Urosome (Fig. 3A) $628 \mu \mathrm{m}$ long and 6-segmented. Fifth pedigerous somite narrow, $115 \mu \mathrm{m}$ wide. Genital somite $252 \times 207 \mu \mathrm{m}$, longer than wide. Four abdominal somites $52 \times 75,43 \times 73,30 \times 68$, and $53 \times 83$ $\mu \mathrm{m}$. Caudal ramus $130 \times 35 \mu \mathrm{m}, 3.71$ times as long as wide.

Rostrum as in female. Antennule with 1 additional aesthetasc on second and fourth segments at places indicated by dots in Fig. 1D. Antenna (Fig. 3B) additionally with rows of scales (spinules) on proximal half of inner margin of second segment; fourth segment more longer than that of female, $90 \times 21 \mu \mathrm{m}, 4.29$ times as long as wide.

Labrum, mandible, maxillule, and maxilla not different from those of female. Maxilliped (Fig. 3C) consisting of 3 segments and terminal claw; first segment longest but unarmed; second segment with 1 longitudinal row of spinules, 2 unequal setae (one of them broad, with serrate margins), and 1 pointed distal process on expanded inner margin; small third segment unarmed; terminal claw strong, proximally with 2 extremely unequal setae.

Leg 1 with third endopodal segment bearing 2 spines and 4 setae (armature formula I,I,4). Legs $2-4$ as in female. Free segment of leg 5 (Fig. 3E) quadrangular, $57 \times 13 \mu \mathrm{m}, 4.38$ times as long as wide, with few spinules on outer margin; 2 terminal setae 87 (outer) and $26 \mu \mathrm{m}$ (inner). Leg 6 represented by 2 subequal setae on genital flap (Fig. 3A).

\section{DISCUSSION}

The genus Paramolgus has been known of 34 species, including the new species $P$. orientalis, as associates of various cnidarians. Four of them discovered from the antipatharian corals: Paramolgus constrictus (Humes, 1969) from Antipathes ericoides Pallas in Madagascar; P. insectus (Humes, 1969) from Antipathes cf. spinescens Gray and A. myriophylla Pallas (Humes, 1969) both hosts in Madagascar, from Antipathes abies Linnaeus in the Moluccas (Humes, 1979), and from Antipathes sp. in the Philippines (Humes, 1992), and $P$. delicatulus Humes, 1992 from Antipathes sp. in the Philippines (Humes, 1992).

Humes and Stock (1973) pointed that $P$. constrictus Humes, 1969 and $P$. insectus Humes, 1969, both being all known speices of Paramolgus associated with antipatharians until that time, revealed three unusual features that (1) the female genital double-somite has a lateral notch on the lateral margins, (2) the second segment of male antennule has only one additional aesthetasc distally, and (3) the maxillule has three distal setae. Paramolgus delicatulus Humes, 1992, which was later described without males, confirmed the first and third points. The discovery of $P$. orinetalis n. sp. confirms the first and second points but not the third, because it carries four setae on the maxillule. Thus the latter feature alone can differentiates $P$. orientalis from the three allies.

The species of Paramolgus associated with antipatharians constitute a cohesive group. The most distinctive feature they exhibit seems to be the possession of the laterally notched female genital double-somite, which is not observable in other species of Paramolgus. The possession of the only one aesthetasc on the second segment of the male antennule is also characteristic, although the male of $P$. delicatulus has not been known, in consideration that the male antennule of the family Rhynchomolgidae to which Paramolgus belongs generally carries two aesthetascs on the same segment (Humes and Boxshall, 1996).

Paramolgus orientalis can be distinguished from the three species by several differences, in addition to the difference in the setation of the maxillule. The caudal ramus in the female of $P$. orientalis is 4.22 times as long as wide, which is compared to 1.88 times in $P$. constrictus, 2.65 times in $P$. insectus, and 1.36 times in P. delicatulus (see Humes, 1969, 1992).

The closest relative of $P$. orientalis is $P$. insectus. Both species have similar antenna and maxilla. The antenna of $P$. orientalis and $P$. insectus is slender and its terminal segment is especially elongated. On the other hand, the antenna of $P$. constrictus and $P$. delicatulus is stout and one of setae on its third segment is enlarged. In $P$. orientalis and $P$. insectus the maxilla has a well-developed distal lash and an inner seta both bearing a number of spinules on distal margin, whereas in $P$. constrictus and $P$. delicatulus the maxilla has a small distal lash with fewer spinules and a small or naked inner seta.

Paramolgus orientalis can be distinguished from $P$. insectus by the differences revealed on the maxillule and caudal ramus, as mentioned above. The presence of the scale-like spinules on the inner margin of the second antennal segment in the male seems to be a typical trait of $P$. orientalis. This sexually dimorphic trait was not reported in $P$. constrictus and $P$. insectus where males were known.

Among the four species, $P$. insectus shows the broadest range of distribution and hosts. It is considered that some of ancient population of $P$. insectus had been isolated to the Far Eastern sea and then become to $P$. orientalis through a speciation.

\section{ACKNOWLEDGEMENTS}

This research was carried out as a part of the project "The Discovery of Korean Indigenous Species" supported by the National Institute of Biological Resources (NIBR), Korea. 


\section{REFERENCES}

Humes, A.G., 1969. Cyclopoid copepods associated with antipatharian coelenterates in Madagascar. Zool. Mededel., 44 (1): $1-30$

Humes, A.G., 1979. Poecilostome copepods associated with antipatharian coelenterates in the Moluccas. Beaufortia, 28 (347): 113-120.

Humes, A.G., 1992. Copepoda associated with the thorny coral Antipathes (Antipatharia) in the Indo-Pacific. J. Nat. Hist., 26: 709-744.

Humes, A.G. and G.A. Boxshall, 1996. A revision of the lichomolgoid complex (Copepoda: Poecilostomatoida), with the recognition of six new families. J. Nat. Hist., 30: 175-227.

Humes, A.G. and J.H. Stock, 1973. A revision of the family Lichomolgidae Kossmann, 1877, cyclopoid copepods main- ly associated with marine invertebrates. Smithson. Contr. Zool., 127: 1-368.

Kim, I.-H., 1998. Illustrated Encyclopedia of Fanuna \& Flora of Korea. Vol. 38. Cirripedia, Symbiotic Copepoda, and Pycnogonida. Ministry of Education, Korea, 1038 pp.

Kim, I-.H., 2006. Poecilostomatoid copepods (Rhynchomolgidae) associated with sea anemones (Actiniaria) from Korea. Integrative Biosciences, 10: 145-161.

Kim, I.-H. and J.-G. Je, 2000. Two new species of Asterocheridae (Copepoda, Siphonostomatoida) from Korea. Korean J. Biol. Sci., 4(4): 305-314.

Opresko, D.M. and J.A. Sanchez, 2005. Caribbean Shallowwater Black Corals (Cnidaria: Anthozoa: Antipatharia). Caribb. J. Sci., 41(3): 492-507.

Received January 27, 2010 Accepted March 11, 2010 